\title{
Understanding settlement-landscape interaction with literary records and geoinformatics: The case of Homer's Late Bronze Age Southeast Aegean
}

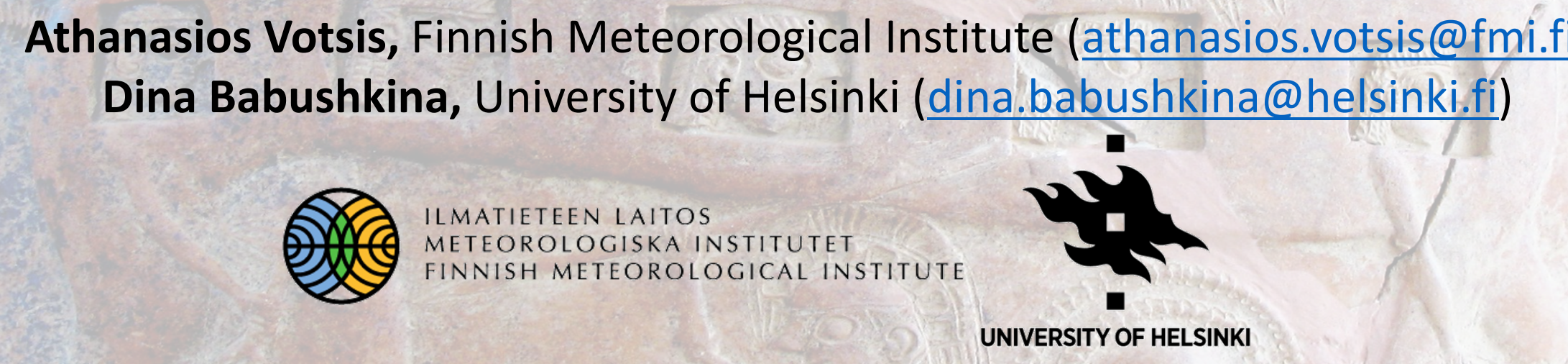

EGU2020 - Co-production and evolution in human-landscape interaction: from geoarchaeological records to geomorphological dynamics and human influence

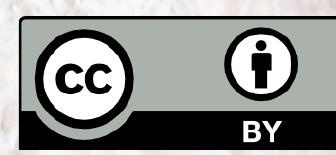




\section{Background}

Advances in Digital Humanities provide rich research material for understanding:

(1) environmental and locational attributes of ancient settlements,

(2) the regional structure of systems of settlements,

(3) social-cultural drivers of human-landscape interaction. 
Can we get a glimpse into the hierarchy of values?

\section{Sustainability research: long-shot objectives}

\section{Can we reasonably conclude about the connection between modern settlement-environment markers/values and the inherent sustainability of ancient settlements?}

Can we reasonably assume what original settlementenvironment markers/values are the most relevant for settlement sustainability? 


\section{Case study from Late Bronze Age SE Aegean}

Catalog of Ships, Iliad 2.494-759

- We present a georeferenced version of the record of cities and their sociocultural and environmental descriptions.

- We combine with data on the spatial and temporal context of those settlements.

- We present first steps in using such methods to answer our long-shot questions. 


\section{Case study from Late Bronze Age SE Aegean}

\section{In the Iliad, Book 2 494-759, Homer lists:}

- the names of Mycenaean cities that attacked Troy ( $\mathrm{N}=183)$

- clustered by leader and agglomeration (or region, territory)

- the number of ships that each city brought to the Mycenaen alliance

- qualitative description of prominent features, associations of cities $(\mathrm{N}=66)$

[...] Of the Boeotians Peneleos and Leïtus were captains, [495] and Arcesilaus and Prothoënor and Clonius; these were they that dwelt in Hyria and rocky Aulis and Schoenus and Scolus and Eteonus with its many ridges, Thespeia, Graea, and spacious Mycalessus; and that dwelt about Harma and Eilesium and Erythrae; [500] and that held Eleon and Hyle and Peteon, Ocalea and Medeon, the well-built citadel, Copae, Eutresis, and Thisbe, the haunt of doves; that dwelt in Coroneia and grassy Haliartus, and that held Plataea and dwelt in Glisas; [505] that held lower Thebe, the well-built citadel, and holy Onchestus, the bright grove of Poseidon; and that held Arne, rich in vines, and Mideia and sacred Nisa and Anthedon on the seaboard. Of these there came fifty ships, and on board of each [510] went young men of the Boeotians an hundred and twenty. [...] 


\section{Georeferencing}

1. Projects Topos Text (by Brady Kiesling) and Pleiades (Ancient World Mapping Center, Stoa Consortium, Institute for the Study of the Ancient World) were used to derive/validate the coordinates of each settlement.

2. The Pleiades project was additionally used to append information on the known (or postulated) lifespan of each settlement, based on the minimum and maximum chronologies of the settlement.

3. Programmatic georeferencing with available gazetteers using Python language is still under testing and currently not as good as manual geocoding. 


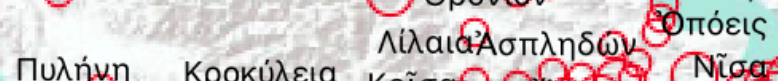

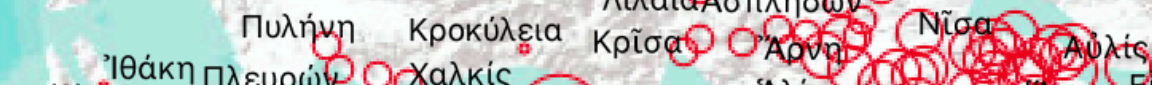

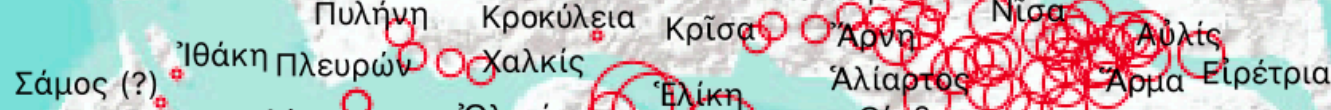

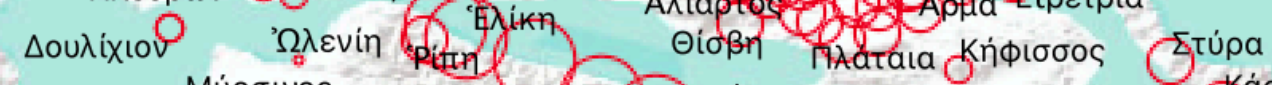

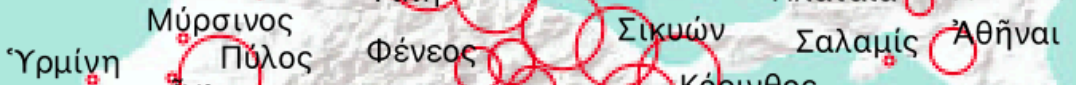

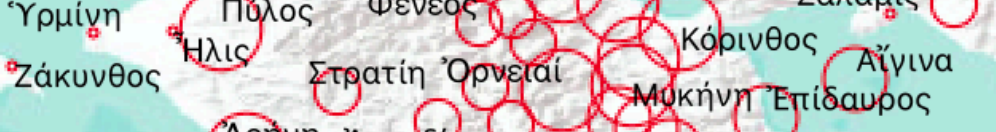
Aptivn Apkdsia

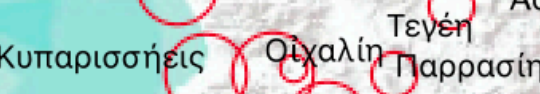

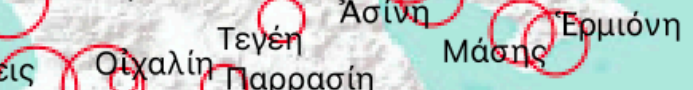

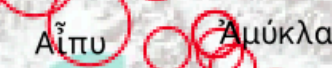
Bpuoriat ateros oíturos siáas पघ́ंбon

Kápuotos

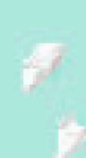

v

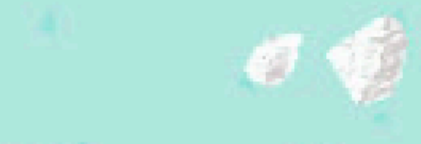

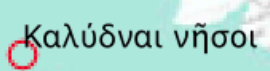

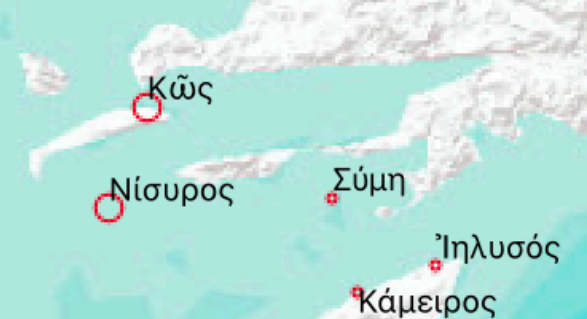

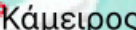
nivoos 


\section{Analysis of implicit}

values 


\section{Relation between modern sustainability markers and values implicit in Homer's descriptions}

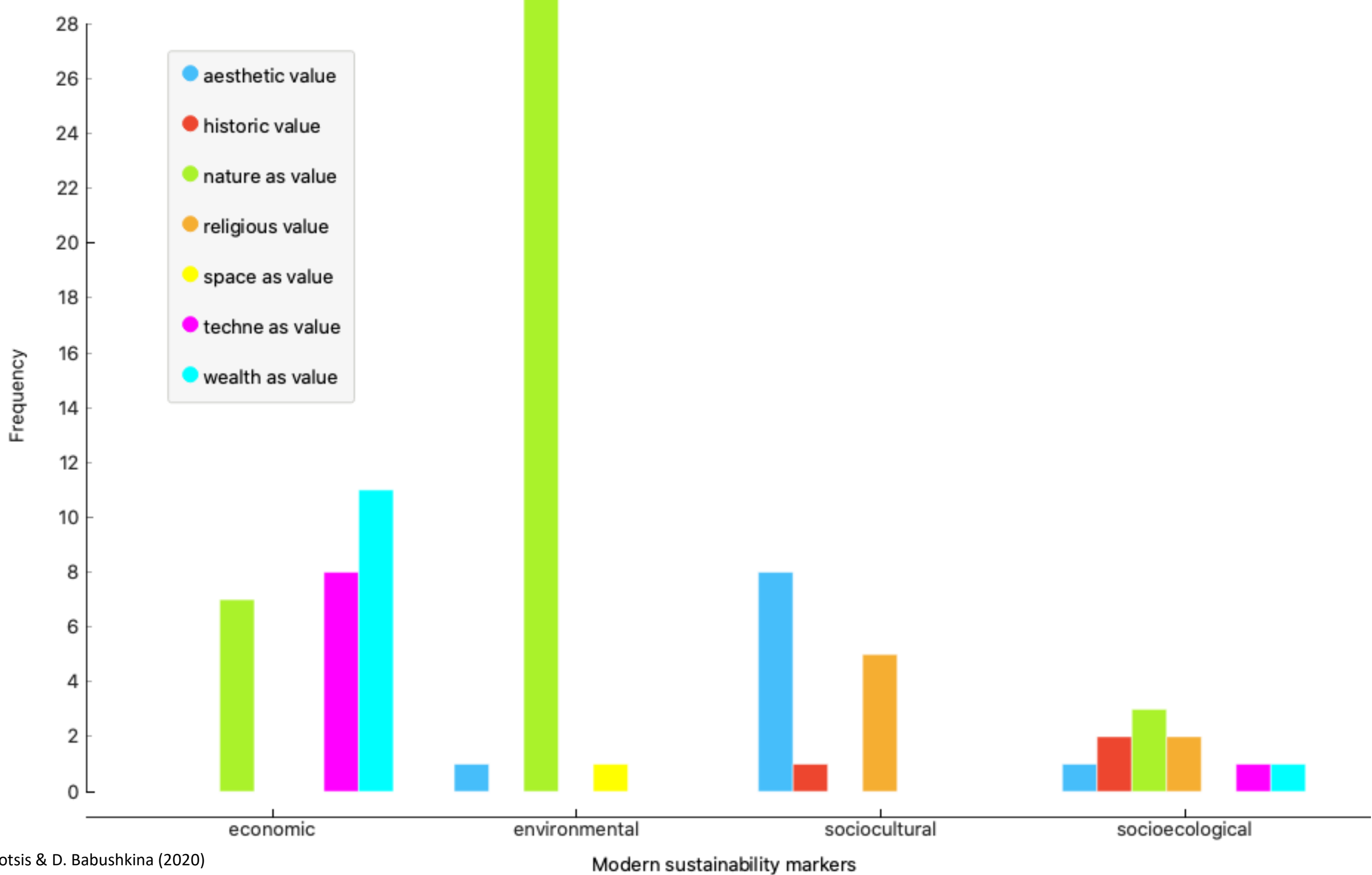


Regional structure 
Methone, Thaumacia, Meliboia, Olizon)

(Phylake, Pyrasus, Iton, Antrum, Pteleumlo

Myrmidons, Hellenes,

Enienes, Peraeboi 2

Cephallenians Aetolia
ulichium, Echipean islandsD

Boeotians 2 (Aspleidon, Ofenomenas) focreans

(Dulichium, Echimean islandsD

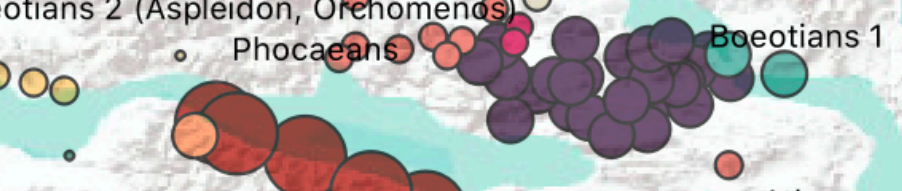

- \&pans

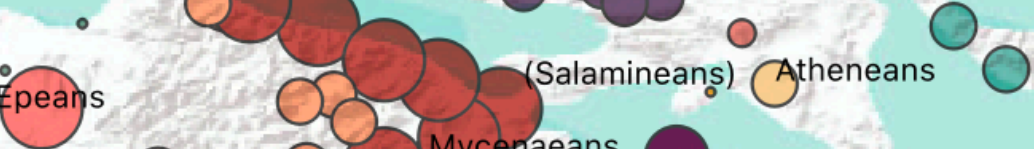

\section{.}

- 202 mycemaeans

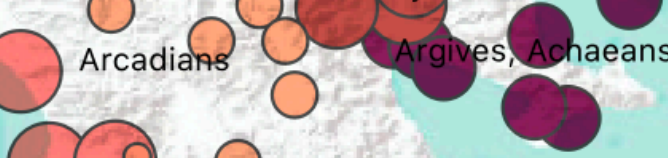

(O) 0

Lacedaemonians

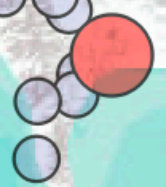

O

\section{Symeans}

QNisyrus, Carpathus, Casus, Kos, Eurypylos, Calyd 


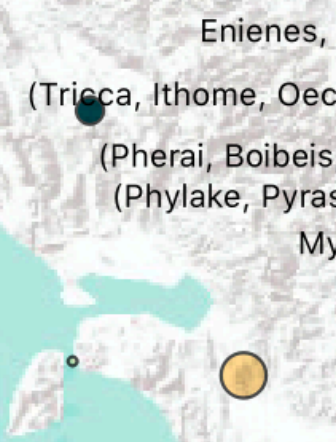

\section{.8.}

oibeis, Boebe Glaphyrae, lolkos) (Qrmenios, Hyperia, Asterios, Titanus)

Myrmidons, Hellenes, Acheans Enienes, Peraeboi 2

ephallenians

(Dulichium, Echinean islands)
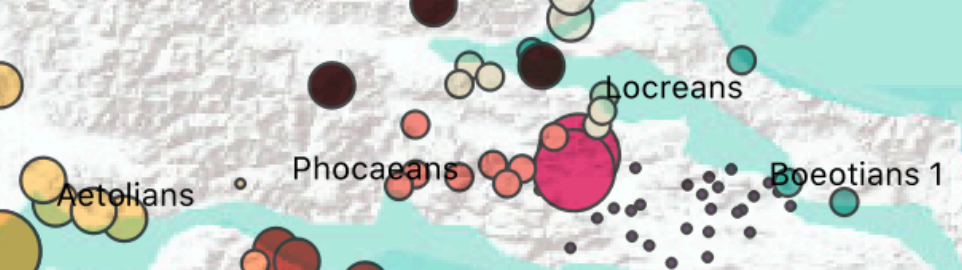

- deans

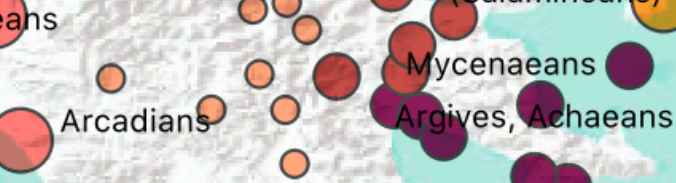

080

308 acedaemonians

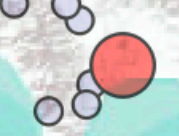

0

(Nisyrus, Carpathus, Casus, Kos, Eurypylos, Calydnian islands
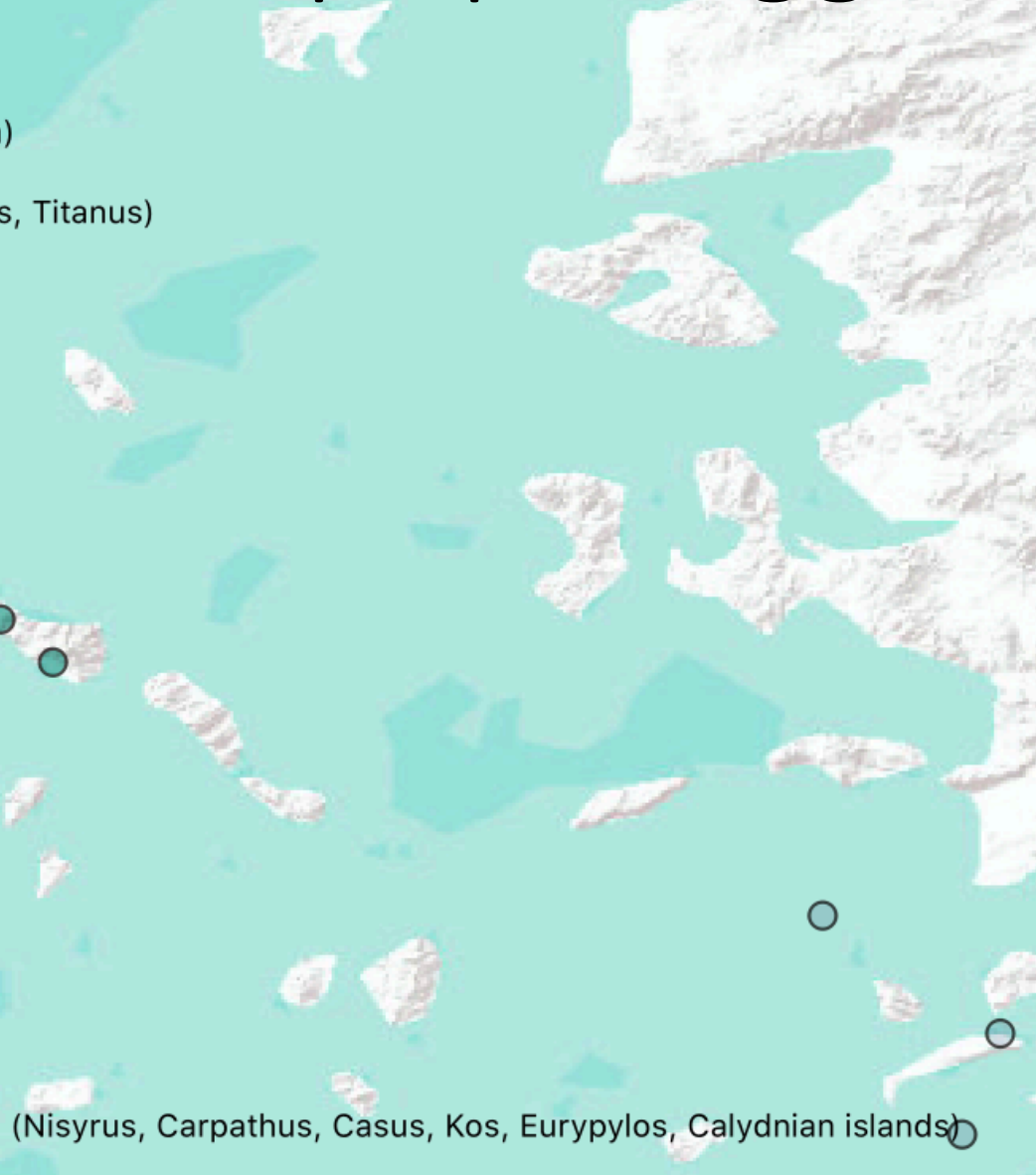

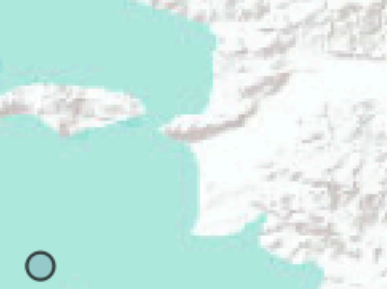

0

Symeans 


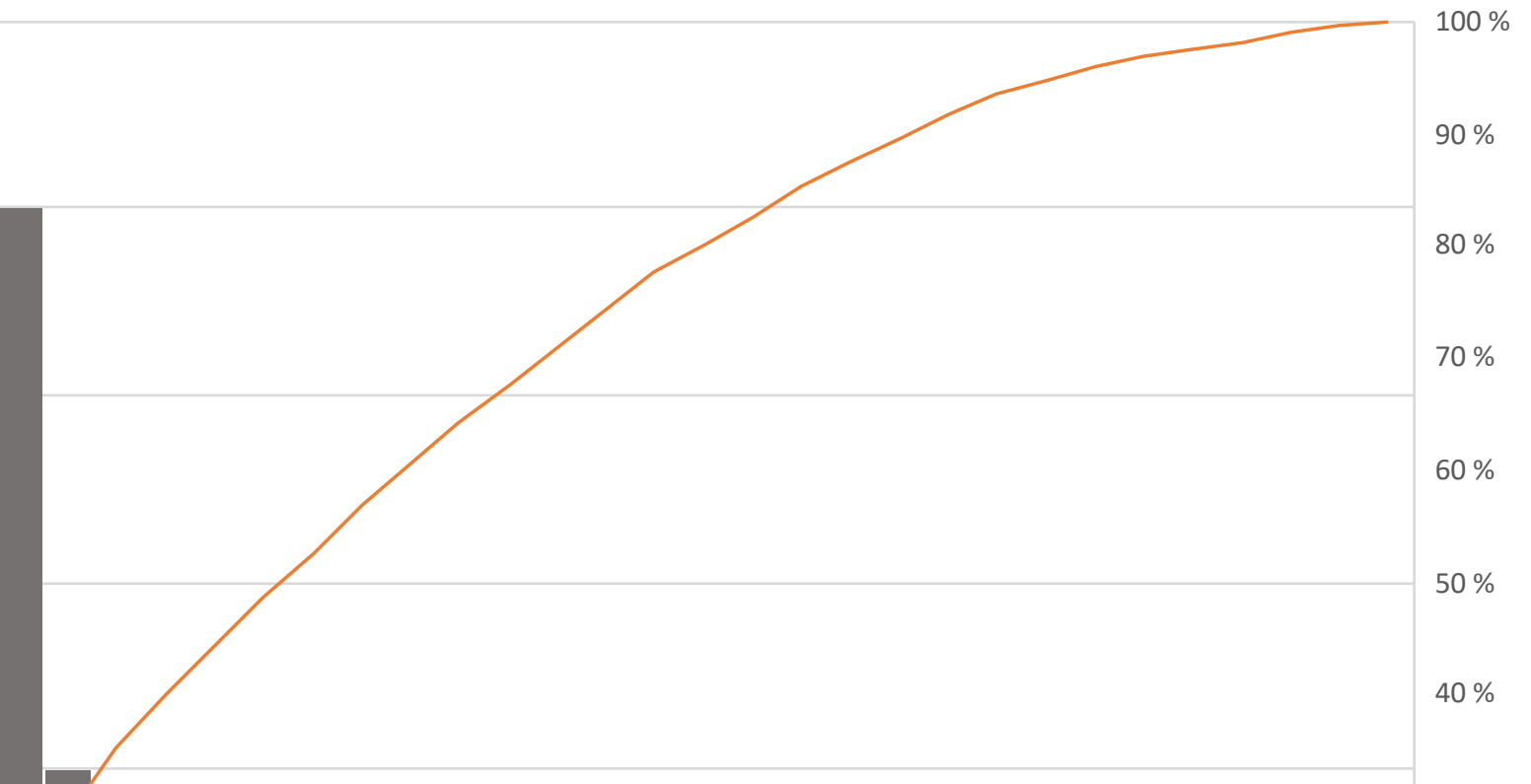

20.00

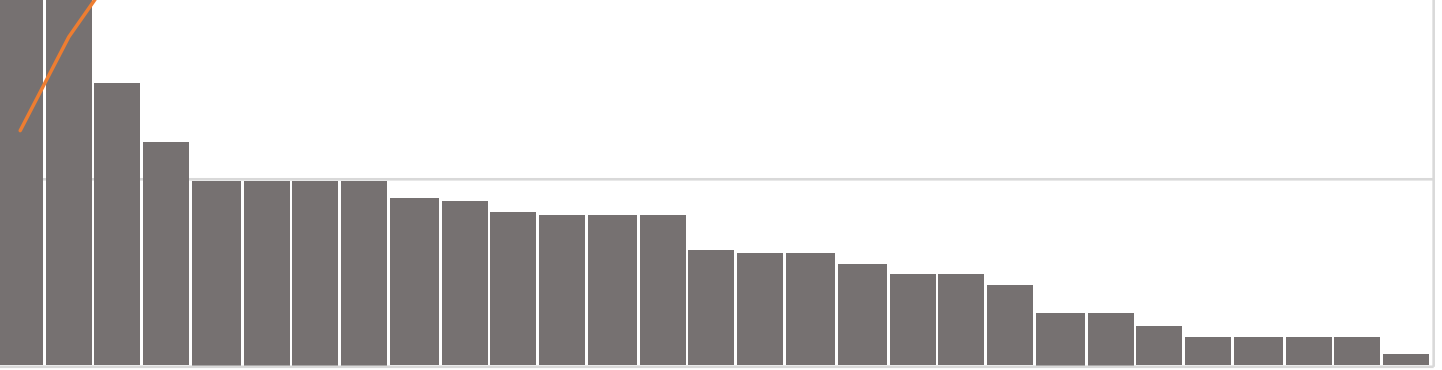

0.00

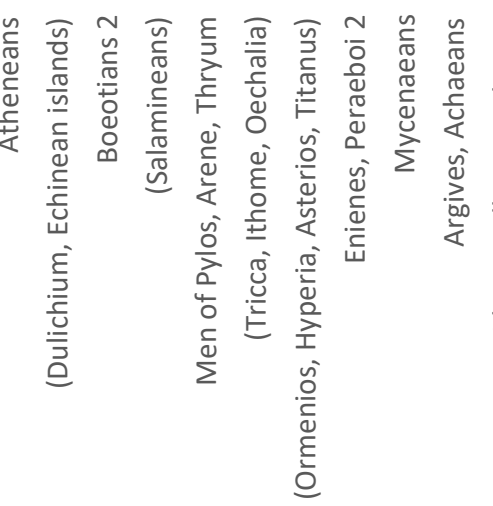

$30 \%$

$20 \%$
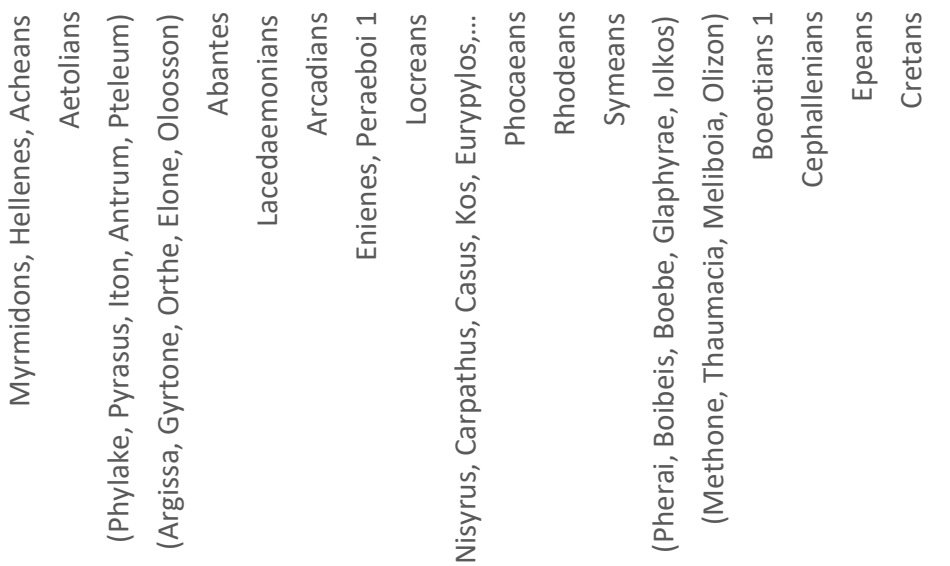

A. Votsis \& D. Babushkina (2020)

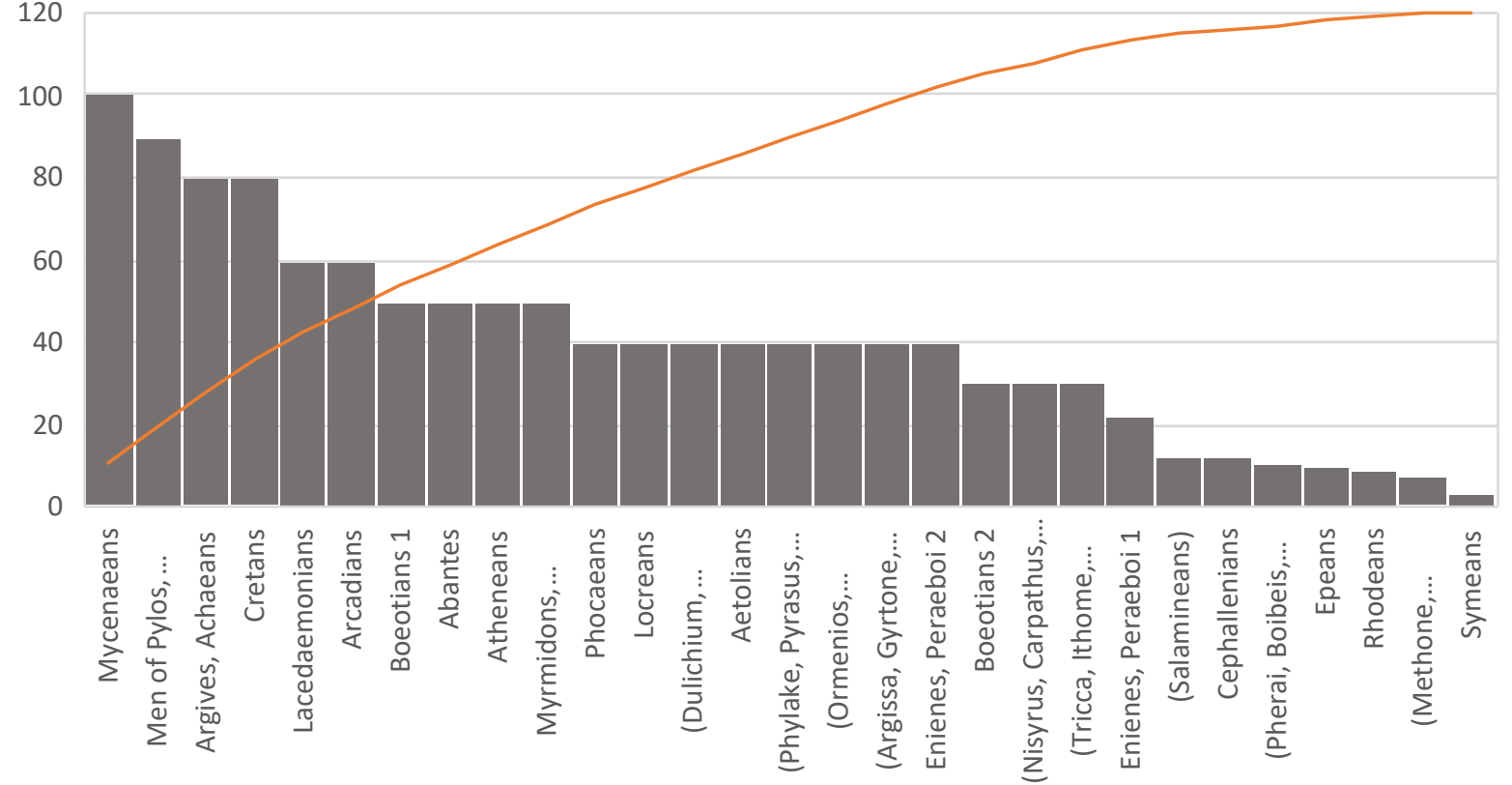

Afgglomeration size (number of cities per agglomeration)

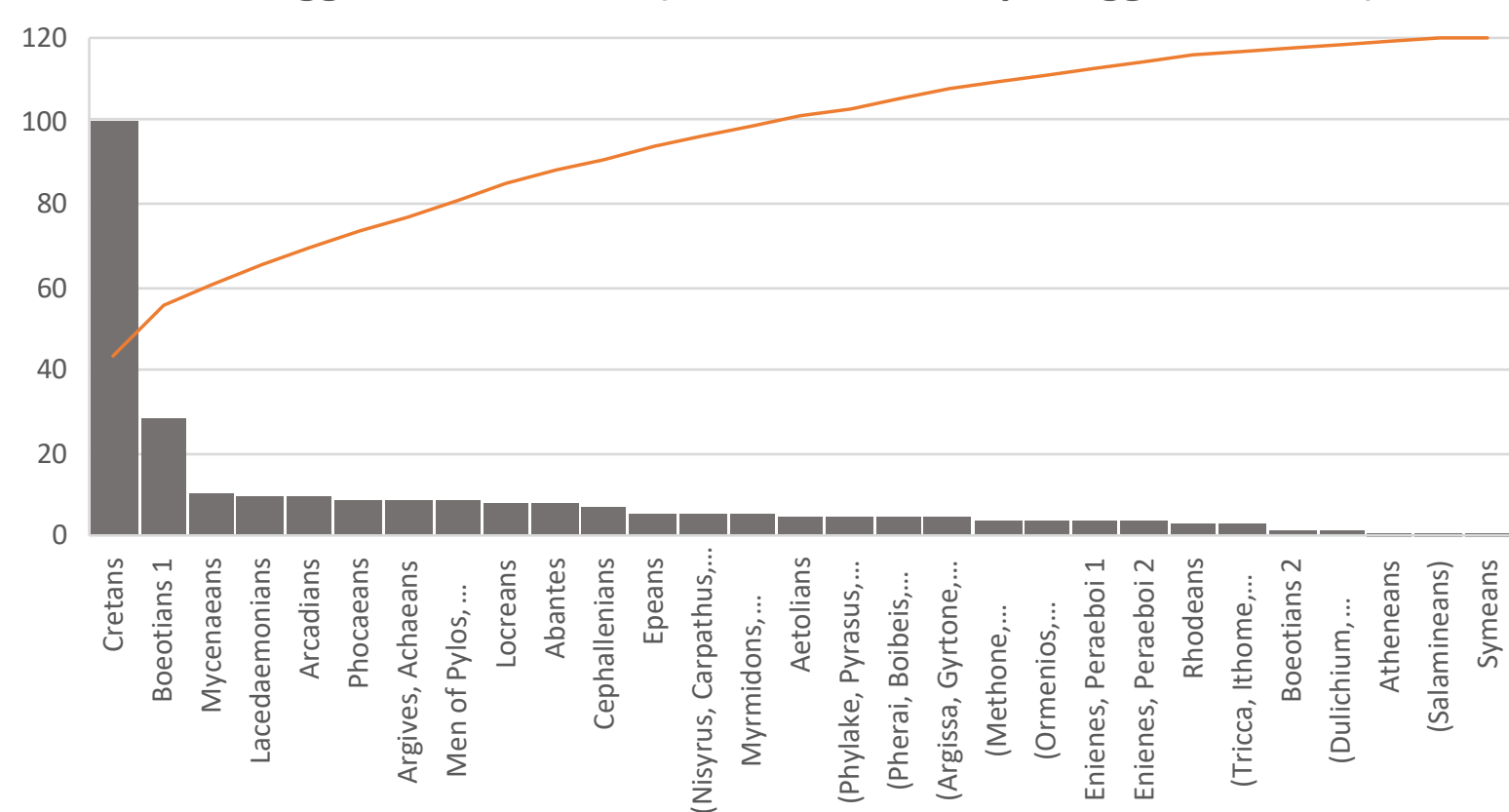

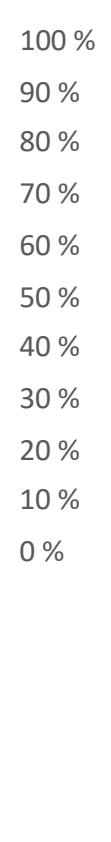

$100 \%$ $90 \%$ $80 \%$ $70 \%$ $50 \%$ $30 \%$ $10 \%$ 更 


\section{Does regional structure or power correlate with settlement lifespan?}
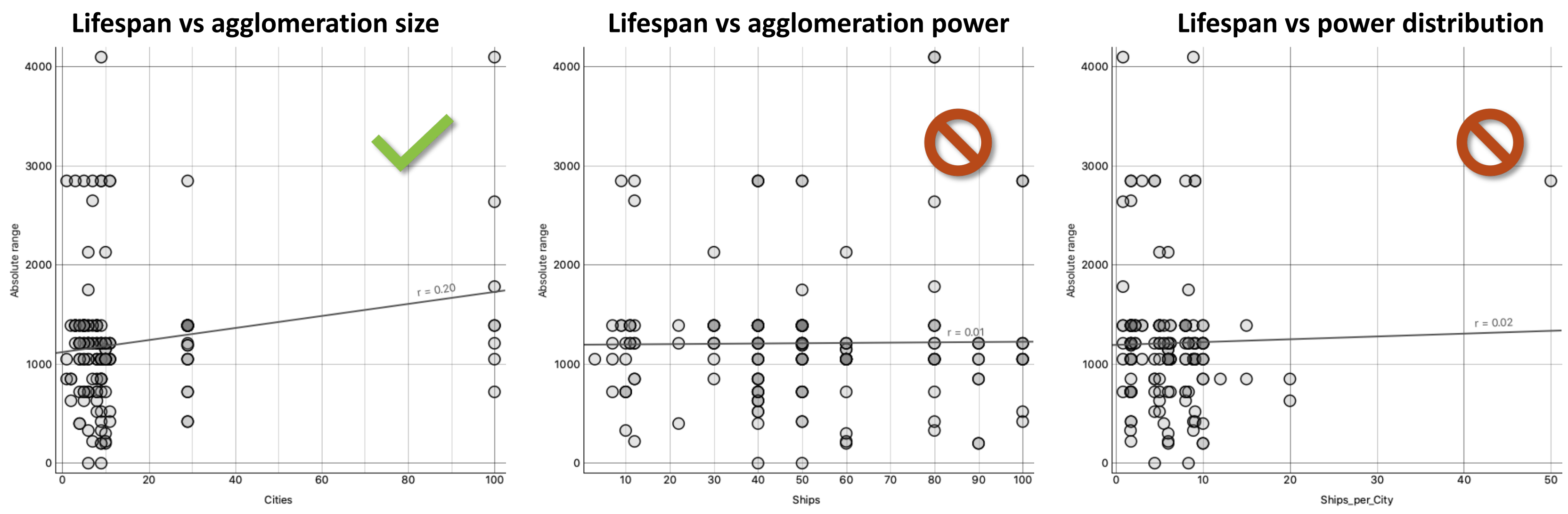
Sustainability and value hierarchy 


\section{Sustainability markers: lifespan, regional footprint}

Influence on lifespan of settlement

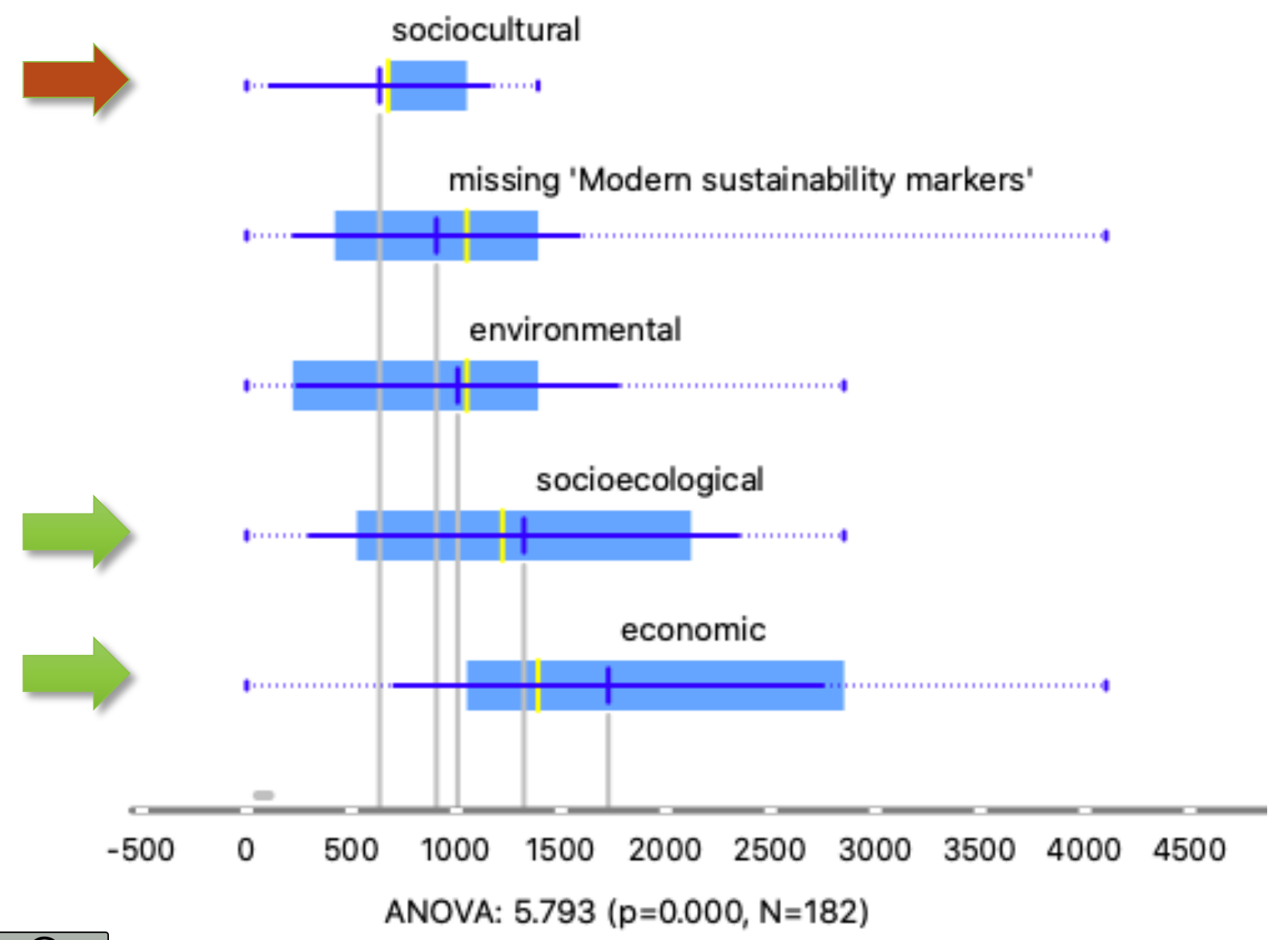

Influence on agglomeration size

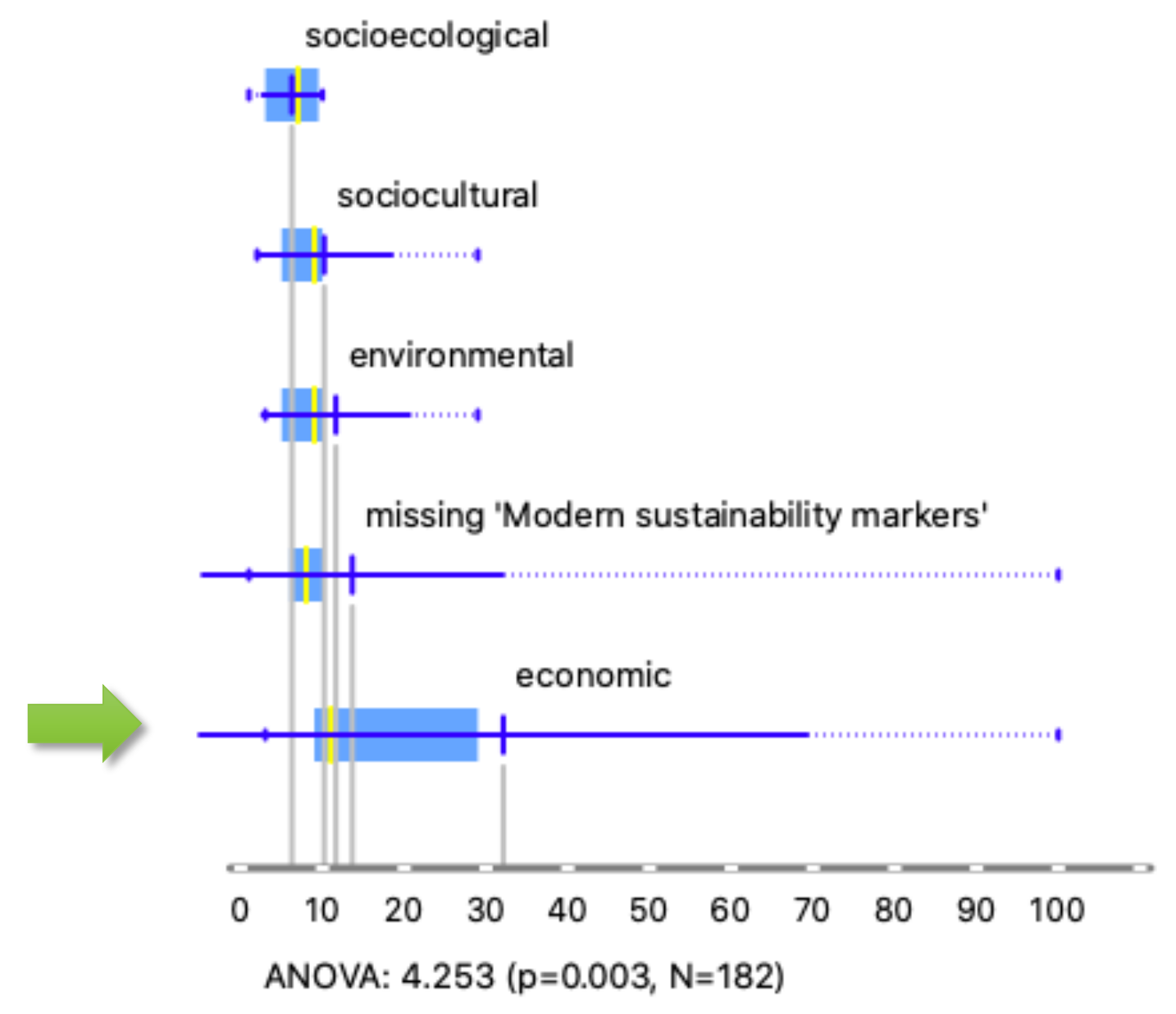




\section{Sustainability markers: power, power distribution}

Influence on power

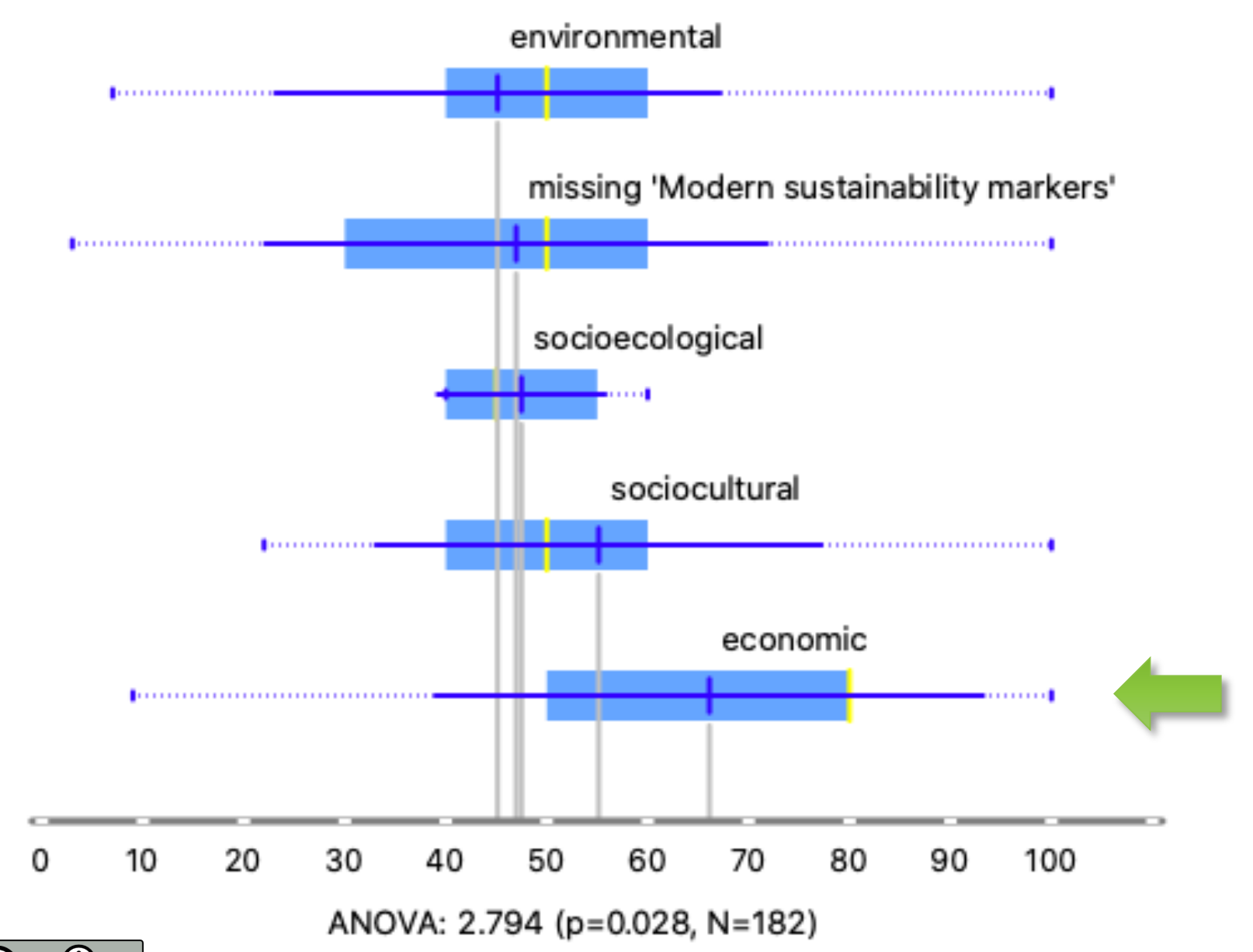

Influence on power distribution

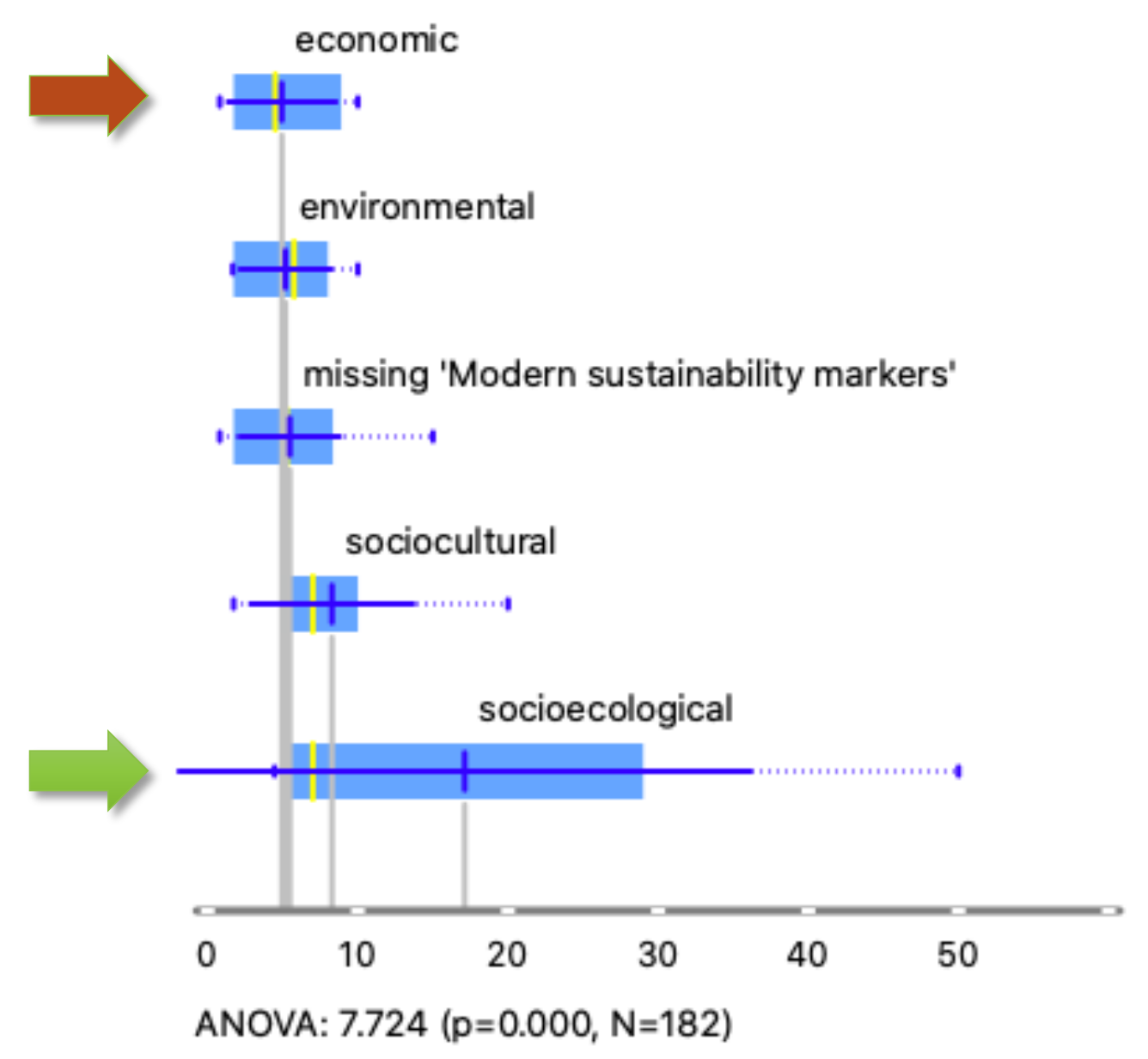




\section{Elements of landscape: lifetime}

\section{(insignificant influence on regional}

footprint, power, and power diversity)

Influence on lifespan of settlement

plants

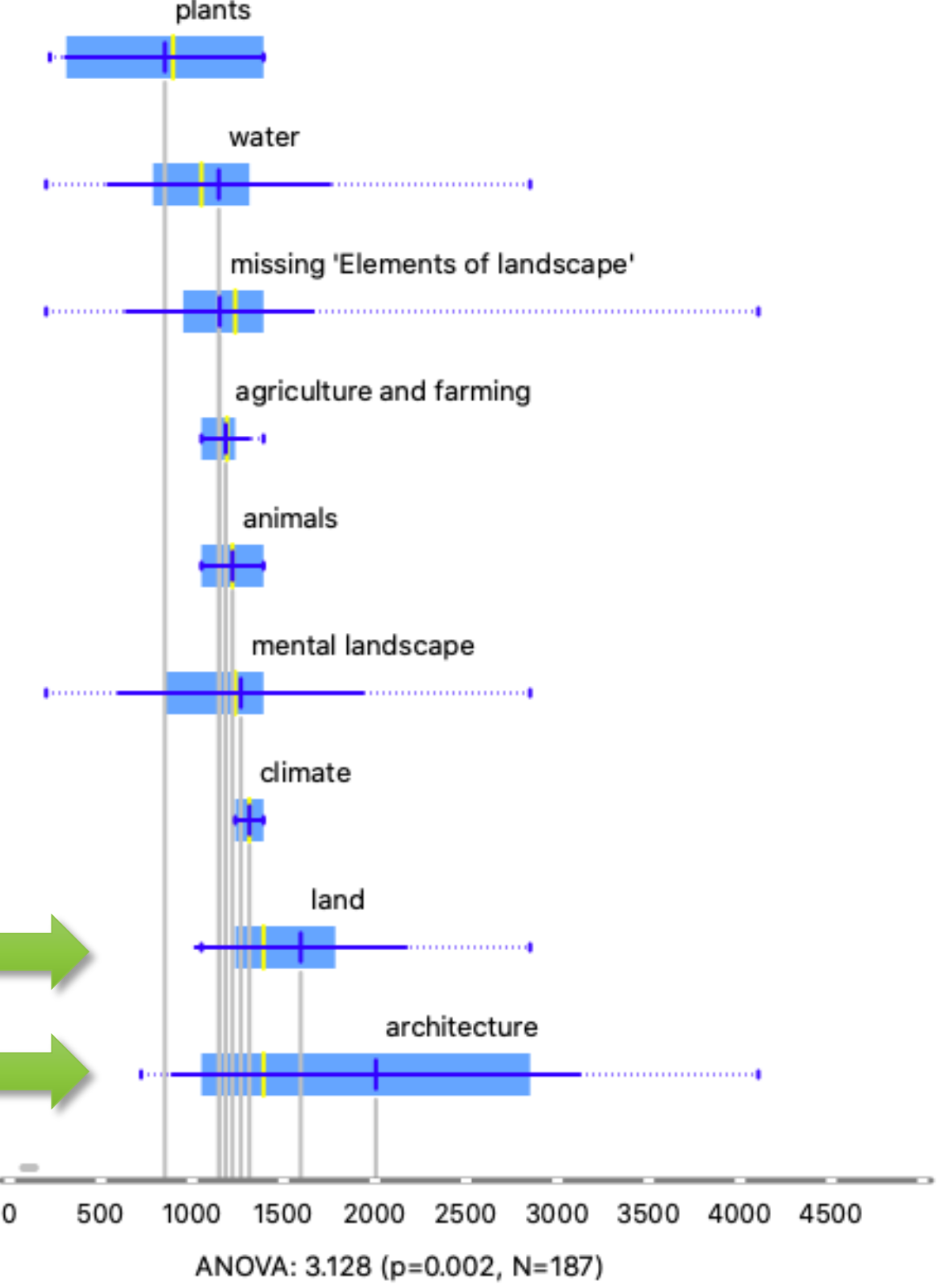




\section{Prospects \& Limitations}

Such research does provide valid and valuable knowledge (based on our first results) for understanding human-environment interaction as well as settlement sustainability, but:

- Informing our sustainability research by the analysis of the historic material confirms the need to re-think the very concept of sustainability, which appears to be goal-oriented and value-loaded. What do we want to achieve when setting sustainability goals and what markers should be used to evaluate our progress?

- The dataset should be well-prepared, e.g. based on the original text (translations introduce ambiguity and errors).

- Results should be cross-checked with research in relevant disciplines (e.g. historical evidence, other literature).

- Ensure that modern meaning is not read into ancient terms, and where necessary ancient terms must be placed into their context.

- All this highlights the importance of interpretative work done by an expert in the studied topic/field.
Can we get a glimpse into the hierarchy of values?

Can we reasonably conclude about the connection between modern settlementenvironment markers/values and the inherent sustainability of ancient settlements?

Can we reasonably assume what original settlement-environment markers/values are the most relevant for settlement sustainability? 


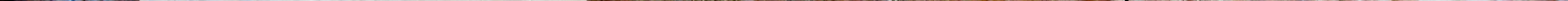

